\title{
First record of Pinnularia subinterrupta Krammer \& Schroeter in Poland - a rare species in Europe
}

\author{
Teresa Noga ${ }^{1 *} \&$ Mateusz Rybak ${ }^{2}$
}

${ }^{1}$ Department of Soil Studies, Environmental Chemistry and Hydrology, Faculty of Biology and Agriculture, University of Rzeszów, Zelwerowicza 8B, 35-601 Rzeszów, Poland

${ }^{2}$ Department of Agroecology, Faculty of Biology and Agriculture, University of Rzeszów, Ćwiklińskiej 1a, 35-601 Rzeszów, Poland

*corresponding author (e-mail: tnoga@ur.edu.pl)

\begin{abstract}
The first record of occurrence of Pinnularia subinterrupta Krammer \& Schroeter in Poland with the species ecological and morphological characteristics (including scanning electron microscope details) are provided. The species was observed in the material collected from the Jamów and Tokarka streams, flowing from the areas of raised bog in the Orava Region of southern Poland. Pinnularia subinterrupta occurred in low abundance, among mosses, and always at low water $\mathrm{pH}$ (3.3-4.8), conductivity $\left(28-63 \mathrm{mS} \mathrm{cm}^{-1}\right)$ and temperature $\left(3.9-9.6^{\circ} \mathrm{C}\right)$.
\end{abstract}

Key words: rare diatom taxon; taxonomy; ecology; SEM photographs

\section{Introduction}

Rare diatom taxa most often occur in low abundance or in a limited number of sites. They may inhabit narrow ecological niches and, therefore, may be good indicators of very specific conditions (Magurran 2004). Many of rare and poorly known diatoms in France were found by Coste \& Ector (2000). In Central Europe, some rare taxa occurring in springs and peat bogs, were noted by Werum \& Lange-Bertalot (2004) and Wojtal (2013). Also in Poland, many rare taxa of the Pinnularia genus (including some taxa new for Polish diatom flora) were observed (Noga et al. 2014).

Representatives of the genus Pinnularia occur most often in fresh waters and rarely in salty waters as epipelic algae. They prefer oligo- and dystrophic waters with low electrolyte content (Krammer \& LangeBertalot 1986; Round et al. 1990; Krammer 2000; Hofmann et al. 2011; Bąk et al. 2012). P. subinterrupta Krammer \& Schroeter was recorded under this name by Krammer (1992). It was first described by Hustedt (1924) as P. interrupta var. minutissima Hust., from the Sarek mountains of Swedish Lapland. The species was also individually noted in the northern hemisphere, i.e., in the Canadian High Arctic Archipelago (Antoniades et al. 2004), Republic of Korea (Joh 2012), Russia
(Medvedeva \& Nikulina 2014), the Czech Republic (Veselá 2009; Veselá \& Johansen 2009), Ireland (Wolnik $\&$ Carter 2014) and Germany (Lange-Bertalot \& Steindorf 1996). The species has not been yet observed in Poland.

The aim of this study was to present additional data (morphological characteristics, ecological notes) and new distribution sites of $P$. subinterrupta that would expand our knowledge of this rare species. A few algological studies conducted previously on the territory of the Orawsko-Nowotarska Basin (Grzelewska 1974; Wasylik 1960, 1993; Wojtal et al. 1999) concerned different algae groups, but did not demonstrate the presence of $P$. subinterrupta in any studied locations. In the Chyżny, Jamów and Tokarka streams, however, no algological studies have been conducted.

\section{Study area}

The studies were conducted in the Chyżny, Jamów and Tokarka streams flowing from raised bogs in the Orawsko-Nowotarska Valley, located between the Western Beskids to the north and the SpiskoGubałówka foothills in the south (Fig. 1). The bottom of the valley is situated up to $1000 \mathrm{~m}$ lower than the nearby mountains. The eastern border of the valley 


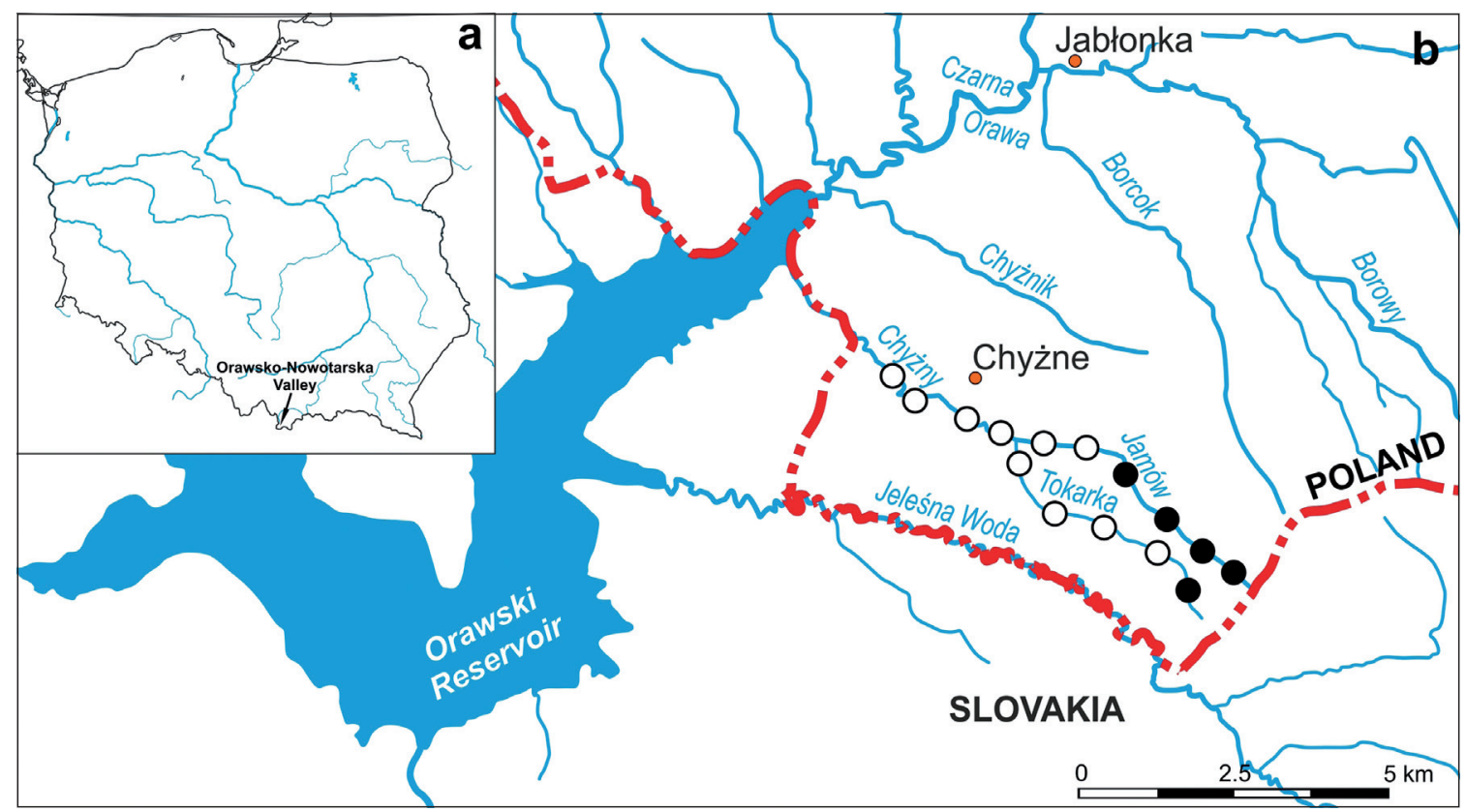

Fig. 1. Location of study area (a), and sampling sites at the Jamów, Tokarka and Chyżny streams (b). Sites with P. subinterrupta records are marked in black

runs along the Main European Watershed between the basins of the Orava and Dunajec rivers. Orava forests create a vast complex of raised bogs and marshy forests (Ladygin 1985; Sobczyński \& Zawadzka 1988; Kondracki 2001).

The Chyżny Stream (approximately $5 \mathrm{~km}$ long) is supplied by two source streams: Tokarka and Jamów. Before reaching the Orava reservoir, it passes through the border between Poland and the Slovak Republic. The Tokarka stream is $5 \mathrm{~km}$ long and the Jamów stream is $3 \mathrm{~km}$ long. The sources of both streams are located in marshy forests on the Polish-Slovak border.

\section{Material and methods}

Material was collected in autumn 2007 and 2011 from the streams: Jamów (6 sites), Tokarka (5 sites) and Chyżny (4 sites). Samples were collected from rocks, mud and mosses growing on stones, and were preserved in $4 \%$ formaldehyde solution. In order to obtain pure valves of diatoms, a part of the obtained material was subjected to maceration in a mixture of sulphuric acid and potassium dichromate at 3:1 proportion and rinsed in a centrifuge (at 2500 revolutions $/ \mathrm{min}$ ). Solid diatom slides were fixed in Pleurax synthetic resin. The material was collected and processed according to the methods applied by Kawecka (1980).

Diatoms were identified using light microscopes (LM): Nikon ECLIPSE 80i and an A2 Carl Zeiss Axio Imager (magnification 1000x) with DIC (Differential Interference Contrast) according to the keys by Krammer $(1992,2000)$. The images were taken under both light microscopes and a HITACHI SU8010 scanning electron microscope (SEM). Species composition in the samples was determined through counting specimens in randomly selected fields of view under a light microscope. Four hundred valves were counted. Species with a content of above $5 \%$ in a given diatom assemblage were defined as abundant.

\section{Results}

Pinnularia subinterrupta was found only in the upper parts of both the Jamów (at four sites) and Tokarka streams (only at one site in 2011), and always as individual specimens $(<0.5 \%$ share in communities). In these streams, $P$. subinterrupta was observed among mosses growing on stones at the stream bottom. At each site, diatom communities were dominated mainly by the species of the Eunotia genus, particularly, E. meisteri Hustedt and E. rhomboidea Hustedt (they exceeded $25 \%$ ). Other dominant species are presented in Table 1. At the sites in the lower parts of all three streams, P. subinterrupta was not found (Fig. 1). This is the first report of this species in Poland.

Tax o nom y

Class: Bacillariophyceae Haeckel 1878 emend. Round et al. (1990)

Subclass: Bacillariophycidae D.G. Mann in Round et al. (1990)

Order: Naviculales Bessey 1907

Suborder: Naviculineae Hendey 1937

Family: Pinnulariaceae D.G. Mann 1990

Genus: Pinnularia Ehrenberg 1843 
Table 1. Physico-chemical parameters and characteristics of Pinnularia subinterrupta locations

\begin{tabular}{|c|c|c|c|}
\hline \multirow{2}{*}{$\frac{\text { Stream }}{\text { Date }}$} & \multicolumn{2}{|c|}{ Jamów stream } & \multirow{2}{*}{$\begin{array}{c}\text { Tokarka stream } \\
10.2011\end{array}$} \\
\hline & 09.2007 & 10.2011 & \\
\hline $\begin{array}{l}\text { Number of sites where } P \text {. } \\
\text { subinterrupta was found }\end{array}$ & \multicolumn{2}{|c|}{4} & 1 \\
\hline Insolation & \multicolumn{2}{|c|}{ low } & medium \\
\hline Bottom & \multicolumn{2}{|c|}{$\begin{array}{l}\text { stony-muddy, stones and the banks } \\
\text { of the stream covered by mosses }\end{array}$} & $\begin{array}{l}\text { silty-loam, covered by } \\
\text { abundant mosses, mainly } \\
\text { of the Sphagnum genus }\end{array}$ \\
\hline Temperature $\left[{ }^{\circ} \mathrm{C}\right]$ & $8.6-9.6$ & $4.4-5.0$ & 3.9 \\
\hline $\mathrm{pH}$ & $3.3-4.0$ & $3.7-4.2$ & 4.8 \\
\hline Conductivity $\left[\mu \mathrm{S} \mathrm{cm}^{-1}\right]$ & $28-63$ & $48-59$ & 55 \\
\hline $\begin{array}{l}\text { Dominant taxa } \\
(>5 \% \text { abundance })\end{array}$ & $\begin{array}{l}\text { Eunotia meisteri } \\
\text { E. rhomboidea } \\
\text { E. ursamaioris } \\
\text { Tabellaria flocculosa }\end{array}$ & $\begin{array}{l}\text { Eunotia bilunaris } \\
\text { E. exigua } \\
\text { E. meisteri } \\
\text { E. rhomboidea } \\
\text { Frustulia saxonica } \\
\text { Pinnularia subcapitata }\end{array}$ & $\begin{array}{l}\text { Eunotia bilunaris } \\
\text { E. exigua } \\
\text { E. incisa } \\
\text { E. meisteri } \\
\text { E. rhomboidea } \\
\text { E. trinacria } \\
\text { E. ursamaioris } \\
\text { Frustulia saxonica }\end{array}$ \\
\hline
\end{tabular}

Pinnularia subinterrupta Krammer \& Schroeter 1992 in Krammer (1992)

Synonym: Pinnularia interrupta var. minutissima Hustedt (1924)

\section{Morphology}

LM observations. Valves were linear, broadly capitate at the ends, had parallel margins with shoulders, in some specimens slightly triundulate. Cells had almost straight and filiform raphe and narrow axial area. Central area was rounded or rhombic. Striae were radiate and becoming convergent towards the ends (Fig. 2a-f).

The valves in the studied material measured: 22.3$24.9 \mu \mathrm{m}$ in length and 4.7-5.0 $\mu \mathrm{m}$ in width; the number of striae was 15 in $10 \mu \mathrm{m}$.

SEM observations. Valve face was flat. Raphe was filiform and the distal ends curved in the same direction. The proximal raphe was drop-shaped and slightly curved in opposite direction to distal ends. In immature cells, each striae was composed of 2 or 3 rows of round pores (Fig. 2i), which were covered by hymens in mature cells (Fig. 2g-h).

\section{Ecology}

In the studied streams flowing from the areas of raised bogs in the Orava region, $P$. subinterrupta always occurred at the sites with low $\mathrm{pH}(3.3-4.8)$, low conductivity $\left(28-63 \mu \mathrm{S} \mathrm{cm}^{-1}\right)$ and low water temperature (3.9$9.6^{\circ} \mathrm{C}$ ). The upper sections of the Jamów and Tokarka streams flow through shaded woodland. The drier areas are dominated by forests with a large share of Picea abies (L.) H. Karst, while in wetlands (swamp forests) prevails Pinus sylvestris L. Banks of the streams were covered by mosses, mainly from the Sphagnum and Polytrichum genera. Bottoms of the streams were also partly covered by mosses (Table 1). Water in the streams was light brown colour, characteristic for water flowing
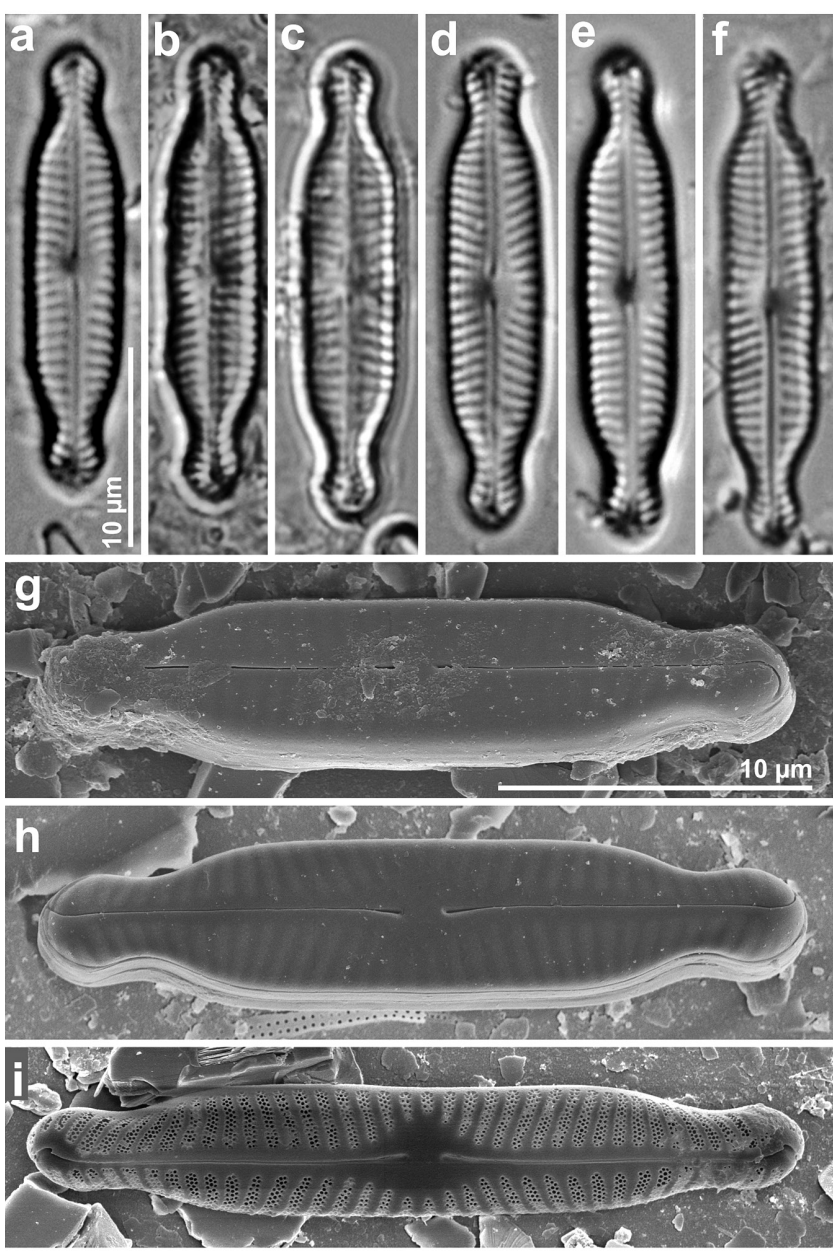

Fig. 2. Pinnularia subinterrupta; light microscope (LM) images: (a-f) and scanning electron microscope (SEM) images (g-i) 
from peat bogs. In the material collected in 2011 from the Tokarka stream, P. subinterrupta was observed only at one site. It was not found in 2007, when water temperature and conductivity were much higher: $15^{\circ} \mathrm{C}$ and $124 \mu \mathrm{S} \mathrm{cm}^{-1}$, respectively. Also, in 2011, at other sites where $P$. subinterrupta was absent, water temperature, $\mathrm{pH}$ and conductivity were much higher, especially in the Chyżny stream ( $\mathrm{pH}$ close to 7 , conductivity above $100 \mu \mathrm{S} \mathrm{cm}^{-1}$ ).

\section{Discussion}

The valves of Pinnularia subinterrupta found in the studied samples were slightly longer and wider than those given by Krammer (1992, 2000): 20-24 $\mu \mathrm{m}$ in length and 4.3-4.6 $\mu \mathrm{m}$ in width, with 14-16 striae in $10 \mu \mathrm{m}$. The diatom cells found in peatlands in Korea were also slightly broader, similarly as in our study (Joh 2012). Moreover, Veselá \& Johansen (2009) reported slightly longer, but not broader cells (16.0-26.5 length, 4.0-4.6 width) from the Czech Republic.

P. subinterrupta occurred in communities dominated by the species of the Eunotia genus, especially, E. meisteri Hustedt and E. rhomboidea Hustedt. Both species preferred acidic, low-electrolyte, oligotrophic or dystrophic waters (Lange-Bertalot et al. 2011).

P. subinterrupta was described for the first time from the Sarek mountains (Swedish-Lapland), from a swamp spring (type locality). It was observed in oligotrophic waters with low electrolyte content (Krammer 1992, 2000). It was also found in two morphotypes in Germany, of which Morphotype II was considered very rare and placed on the Red List as a species of algae currently not considered to be threatened (Lange-Bertalot $\&$ Steindorf 1996). In recent years, the species was observed in the Canadian High Arctic, also in waters with low electrolyte content and circumneutral $\mathrm{pH}$ (Antoniades 2004). It was also found in the streams of the Bohemian Switzerland National Park in the Czech Republic, where it was noted rarely at $\mathrm{pH}$ 3.3-5.3 and conductivity 52-181 $\mu \mathrm{S} \mathrm{cm}^{-1}$ (Veselá 2009; Veselá \&
Johansen 2009), as well as in peat bogs in the Republic of Korea (Joh 2012). According to Van Dam et al. (1994), P. subinterrupta is an acidobiontic $(\mathrm{pH}<5.5)$ and B-mesosaprobous species, occurring in waters of a wide range of trophy (oligo- to eutraphentic). Similar information about the ecology of this species was provided by Alles (1998), who concluded that $P$. subinterrupta was acidobiontic (pH ca. 4) and an indicator of peatbog habitats.

The presented results from the study conducted in the streams of the Orava region, confirmed that this species preferred acidic water with low electrolyte content. Because $P$. subinterrupta was not found in other samples characterized by high $\mathrm{pH}$ and conductivity, it seems that both parameters were the primary determinants of this species development. Also, low water temperature and mosses providing a specific habitat were likely to favour the development of this species.

\section{Conclusion}

Considering the presented findings and the available literature (Alles 1998; Antoniades 2004; Joh 2012; Veselá 2009; Veselá \& Johansen 2009), it can be concluded that Pinnularia subinterrupta seems to be a rare species, growing in low numbers mainly in streams affected by inflows from peat bogs. The species probably occurs in many other places of the northern hemisphere, in specific conditions, but this issue requires further studies expanding current knowledge about the habitat and ecology of $P$. subinterrupta.

The rarity of some species of diatoms (including $P$. subinterrupta) may be related to their narrow ecological preferences and, thus, a small number of suitable habitats, such as streams flowing from mountain bogs. Also, the apparent rarity of such specialist species may result from insufficient examination of their habitats.

Acknowledgments. The authors wish to thank David Duffy for the language correction of the manuscript.

\section{References}

Alles E. 1998. Zur Ökologie der Diatomeen elektrolytarmer Quelle und Bäche unter Berücksichtigung der durch sauren Regen hervorgerufenen Veränderungen der Milieubedingungen. Ph. D. Thesis, University of Frankfurt, Germany.

Antoniades D., Douglas M. S. V. \& Smol J. P. 2004. Diatom species - environment relationships and inference models from Isachsen, Ellef Ringnes Island, Canadian
High. Arctic. Hydrobiol. 529: 1-18. DOI: 10.1007/ s10750-004-4942-8

Bąk M., Witkowski A., ŻElaZna-Wieczorek J., Wojtal A.Z., Szczepocka E., Szulc K. \& Szulc B. 2012. Klucz do oznaczania okrzemek w fitobentosie na potrzeby oceny stanu ekologicznego wód powierzchniowych w Polsce. 452 pp. Biblioteka Monitoringu Środowiska, Główny Inspektorat Ochrony Środowiska, Warszawa. 
Coste M. \& Ector L. 2000. Invasive, exotic or rare diatoms in France: Main observations during the last decades. Syst. Geogr. Pl. 70: 373-4.

Grzelewska E. 1974. Glony torfowiska "Bór na Czerwonem”. Fragm. Flor. Geobot. 20(4): 557-562.

Hofmann G., Werum M. \& Lange-Bertalot H. 2011. Diatomeen im Süßwasser - Benthos von Mitteleuropa. Bestimmungsflora Kieselalgen für die ökologische Praxis. Über 700 der häugfisten Arten und ihre Ökologie. 908 pp. A. R. G. Gantner Verlag K.G., Ruggell.

Hustedt F. 1924. Die Bacillariaceen - Vegetation des Sarekgebirges. Naturwissenschaftliche Untersuchungen des Sarekgebirges in Schwedisch - Lappland. Botanik 3(6): 525-627.

JoH G. 2012. Algal Flora of Korea. Vol. 3(9) Chrysophyta: Bacillariophyceae: Pennales: Raphidineae: Naviculaceae: Biremis, Caloneis I, Pinnularia I. 97-98 pp. Republic of Korea, National Institute of Biological Resources, Ministry of Environment.

KawecKa B. 1980. Sessile algae in European mountains streams. 1. The ecological characteristics of communities. Acta Hydrobiol. 22: 361-420.

Kondracki J. 2001. Geografia regionalna Polski. 441 pp. Wyd. Nauk. PWN, Warszawa.

Krammer K. \& Lange-Bertalot H. 1986. Bacillariophyceae. 1. Teil: Naviculaceae. In: H. Ettr, J. Gerloff, H. Heyning \& D. Mollenhauer (eds.). Süßwasserflora von Mitteleuropa, vol. 2/1, 876 pp. Stuttgard-New York, Gustav Fischer Verlag.

Krammer K. 1992. Pinnularia. Eine Monographie der europäischen Taxa. Bibliotheca Diatomologica 26: 1-353.

Krammer K. 2000. The genus Pinnularia. In: H. LangeBertalot (ed.). Diatoms of Europe, vol. 1, 703 pp. Ruggell, A. R. G. Gantner Verlag K.G.

Lange-Bertalot H. \& Steindorf A. 1996. Rote Liste der limnischen Kieselalgen (Bacillariophyceae) Deutschlands. Schriftenreihe für Vegetationskunde 28: 633-677.

Lange-Bertalot H., Bą M. \& Witkowski A. 2011. Eunotia and some related genera. In: H. LANGE-BERTALOT (ed.). Diatoms of Europe, vol. 6, 148-208 pp. Koenigstein, A. R. G. Gantner Verlag K.G.

Ładygin Z. 1985. 7 dni na Orawie polskiej. Przewodnik turystyczny. 64 pp. Wydawnictwo PTTK Kraj, Warszawa-Kraków.

Magurran A. E. 2004. Measuring biological diversity. 215 pp. Wiley-Blackwell, Australia.

Medvedeva L. A. \& Nikulina T. V. 2014. Catalogue of freshwater algae of the southern part of the Russian Far East. 271 pp. Dalnauka, Vladivostok.
Noga T., Peszek Ł., Stanek-Tarkowska J. \& Pajączek A. 2014. The Pinnularia genus in south-eastern Poland with consideration of rare and new taxa to Poland. Oceanol Hydrobiol St 43(1): 77-99.

Round F. E., Crawford R. M. \& Mann D. G. 1990. The diatoms. Biology \& morphology of the genera. 556-557 pp. Cambridge Univ. Press, Cambridge.

Sobczyński M. \& Zawadzka B. 1988. Orawa polska. Problemy geograficzno-polityczne i społeczne. 2-8 pp. Zarząd Wojewódzki PTTK, Regionalna Pracownia Krajoznawcza, Łódź.

Van Dam H., Martens A. \& Sinkeldam J. 1994. A coded checklist and ecological indicator values of freshwater diatoms from the Netherlands. Netherlands J. Aquatic Ecol. 28: 117-133. http://dx.doi.org/10.1007/ BF02334251

Veselá J. 2009. Spatial heterogeneity and ecology of algal communities in an ephemeral sandstone stream in the Bohemian Switzerland National Park, Czech Republic. Nova Hedwigia 88(3-4): 531-547.

Veselá J. \& Johansen J.R. 2009. The diatom flora of ephemeral headwater streams in the Elbsandsteingebirge region of the Czech Republic. Diatom Research 24(2): 443-477. http://dx.doi.org/10.1080/026924 9X.2009.9705813

WASYLIK K. 1960. Glony torfowisk wysokich Kotliny Nowotarskiej ze szczególnym uwzględnieniem desmidii. Fragm. Flor. Geobot. 7(1): 215-288.

Wasylik K. 1993. The algae of the raised peat bog of the Orawa-Nowy Targ Basin with special reference to the peat bog "Na Czerwonem". Polish Bot. Stud. 10: 63-77.

Werum M. \& Lange-Bertalot H. 2004. Diatoms in Springs from Central Europe and elsewhere under the influence of hydrogeology and anthropogenic impacts. 418 pp. A. R. G. Gantner Verlag K.G., Germany.

Wojtal A., Witkowski A. \& Metzeltin D. 1999. The diatom flora of the "Bór na Czerwonem" raised peat-bog in the Nowy Targ Basin (Southern Poland). Fragm. Flor. Geobot. 44(1): 167-192.

Wojtal A. Z. 2013. Species composition and distribution of diatom assemblages in spring waters from various geological formations in southern Poland. J. Cramer, Gebrüder Borntraeger Verlagsbuchhandlung, Stuttgart. Bibliotheca Diatomologica 59: 1-436.

WOLNIK L. \& CARTER R. T. 2014. Diatoms Ireland http://www. diatomsireland.com. 